\title{
THE HYPOTHETICAL IMPLEMENTATION OF PRESUIT AND PRETRIAL DISCOVERY IN CIVIL LITIGATION IN BRAZIL
}

\author{
POSSIBILIDADES DE IMPLEMENTAÇÃO DA DISCOVERY PROCESSUAL E PRÉ- \\ PROCESSUAL NO ORDENAMENTO JURÍDICO PROCESSUAL BRASILEIRO
}

\section{Rafael Gomiero Pitta}

\begin{abstract}
Doutor em Ciências Jurídicas pelo programa de doutorado da Universidade Estadual Norte do Paraná. Mestre em Ciências Jurídicas pelo programa de mestrado da Universidade Estadual Norte do Paraná. Especialização em Direito Civil e Processo Civil pela Unibalsas. Graduado em Direito pela Universidade Estadual de Londrina. Realizou em 2019 estágio doutoral na Universidade de Granada na Espanha como bolsista pelo programa europeu BeaDoc/Capes. Professor na área de direito processual civil e coordenador do Núcleo de Prática Jurídica nas Faculdades Londrina. E-mail: rafapitta22@gmail.com
\end{abstract}

Eduardo Salomão Cambi

Mestre e Doutor em Direito pela Universidade Federal do Paraná (UFPR). Pós-doutor pela Univesità degli studi di Pavia. Professor da Universidade Estadual do Norte do Paraná (UENP). Promotor de Justiça no Estado do Paraná. Assessor da Procuradoria-Geral de Justiça. Coordenador da Escola Superior do Ministério Público do Paraná. Membro da Academia Paranaense de Letras Jurídicas. E-mail: eduardocambi@hotmail.com

Recebido em: 23/04/2020

Aprovado em: 08/12/2020

\begin{abstract}
Analyzing quantitative data from common law and civil law systems, the first striking comparative difference that draws attention is the number of cases settled and resolved in the early stages of the commom law systems. In both England and the United States (USA) there is a high degree of efficiency in settling and ending cases during the pretrial phase, i.e., even before proceeding to trial. This efficiency, in both U.S. and English law, is due to the use of information and evidence disclosure tools, followed by the possibility of a summary judgement. Although there is no such thing as anglo-american law, especially given the distinction that the english and american models have shown in recent decades, the instruments used in the civil justice systems of these two countries are fertile ground for the study of possible solutions to be implemented in Brazil. This article presents the solutions of the s called anglo-american system and elaborates a proposal for reforms able to introduce the implementation of such instruments in the Brazilian procedural system.
\end{abstract}

Keywords: Common law. Procedural techniques. Presuit/pretrial discovery.

RESUMO: Analisando dados quantitativos dos sistemas de justiça oriundos da família common law e civil law, a primeira diferença comparativa marcante que chama atenção é o número de casos que se encerra nas fases iniciais nos sistemas que adotaram o commom law. Tanto na Inglaterra quanto nos Estados Unidos (EUA) há um alto grau de eficiência na finalização de casos durante o 
pretrial, ou seja, antes mesmo do início da fase de julgamento. Esta eficiência, tanto no direito estadunidente como no inglês, se deve à utilização de instrumentos de revelação de informações e provas, seguido de uma fase de encerramento sumário. Apesar de não existir um direito propriamente anglo-americano, especialmente diante do distanciamento que os modelos inglês e o norte-americano têm demonstrado nas últimas décadas, os instrumentos utilizados nos sistemas de justiça civil desses dois países e revelam campo fértil para o estudo de possíveis soluções a serem implementadas no Brasil. O presente artigo apresenta as soluções do sistema anglo-americano e elabora uma proposta de direcionamento e reformas tendentes a possibilitar a implementação de tais instrumentos no sistema processual brasileiro.

Palavras-chaves: Direito comparado. Técnicas processuais. Produção antecipada de provas. Resolução de litígio.

SUMÁRIO: Introduction; 1 Pretrial and trial: the stages of the Anglo-American system; 2 Evolution of procedural rules in England and in the USA; 3 Emergence and development of discovery in England; 4 The current model of evidence disclosure in the English procedural system and the precedents; 5 Discovery in the United States; 6 The costs of pretrial discovery; 7 Virtual application of pretrial regulation and instruments in the Brazilian procedural system; 8 The brazilian system and the adjustment of the discovery rules; Conclusion; References.

\section{INTRODUÇÃO}

The English justice system is the typical representative of the common law tradition, and the US justice system emerged and developed from the model implemented by the English in the colonies established in the United States, which means, US inherited the basis of English common law and evolved from it. The so called Anglo-American law is the gathering of customs and procedures that these two models have in common. ${ }^{1}$

These models are known for the great efficiency in both pre-suit and pretrial stages ${ }^{2}$, achieving high rates of summary judgements and settlement by conciliation, even before the trial stage is initiated. Understanding the reasons for such efficiency is the starting point to understand how anglo-american solutions may improve the civil procedure system in Brazil.

The efficiency of English and U.S systems can be assigned to many factors, most of them linked to the historical development of the countries. In fact, the adversarial system and the extensive regulation of procedural rules are likely to be the responsible for the high settlement and withdrawal rates in the pretrial stage.

As widely known, english law developed from the conquest of England by the Normans in 1066 and the several mechanisms improved by courts throughout history. At the time of the establishment of the 13 colonies in America, the english law were gradually incorporated into the US justice system and over time became a model of quantitative efficiency.

The U.S. procedural system has developed in a very peculiar way, and just like english law, established a procedural stage prior to trial - the pretrial stage- which, among other features and characteristics, is usually responsible for dismissing the majority of cases in the U.S. courts.

1 In fact, there's no such thing that can be called anglo-american law. However, from the studies on english and US common law, one can observe a series of procedural conducts that repeat, evolve and form a certain pattern, in particular the format inherited from English common law and Anglo-Saxon law, restructured and developed in a very peculiar way in the US.

2 Efficiency here is used from a quantitative perspective, i.e., the anglo-american system has created mechanisms capable of settling a large number of cases before the trial stage, via conciliation and withdrawal. 
The use of procedural discovery in the pretrial stage is a key feature in the US system. Both in the US and in England it is hard to imagine the functioning of the system without a stage of production and reciprocal disclosure of evidence in the early stages of the procedure.

Since the Woolf reforms in 1998, a new feature stands out in the english justice system. This set of measures of the pre-action stage is called pre-action protocols, and function as nonmandatory guidelines addressed to the parties and their lawyers designed to set rules to the early procedure. These guidelines channels to early dialogue between the parties, as well as to provide for measures that tend to settle the dispute by reaching an agreement even before the actual judicial procedure is initiated.

Both english and the american system rely on the method of disclosure of evidence in the early stages of the procedure, which is the prior disclosure and exchange of data, information and evidence between the plaintiff and the defendant, so that they initiate their allegations and the procedural interactions already provided with all the relevant information about the case they intend to bring to the court.

Based on the examination of these procedural techniques, this article intends to discuss the suitability of similar solutions for brazilian law, respecting its sources and traditions, admittedly related to the so-called civil law tradition ${ }^{3}$.

To this end, using the hypothetical-deductive method, the research aims to establish the premise that the brazilian system can benefit from solutions found in the anglo-american procedural system, and as a secondary objective, the research seeks to fully understand the functioning of the pretrial instruments in order to implement the required changes.

\section{PRETRIAL AND TRIAL: THE STAGES OF THE ANGLO-AMERICAN SYSTEM}

It is important to note the distinction between judicial systems evolved from the common law and civil law traditions, especially in relation to the control of judicial acts by parties/lawyers and the two staged civil litigation.

Civil law systems does not formally split the procedure into two stages - pretrial and trial - as it occurs in common law systems. There is a marked difference in the way that common law and civil law developed systems for presenting facts and seeking evidence, i.e., in a continuous way in the common law and episodically in civil law (DAMASKA, 1997, p. 840).

A important difference between the two legal traditions is that common law systems emphasises the pretrial stage and discovery has many valuable mechanisms that are responsible for a large number of settlements and dismisses in this early stage of litigation.

In the civil law systems, the entire procedure is continuous and fully conducted by the court, i.e., there's no pretrial and trial partition. The presentation of arguments, at least most of it, occurs within the initial pleadings, as well as the documentary evidence. The arguments and the main documents are presented jointly with the plaintiff's initial pleading and the defence pleading (answer), respectively.

On the other hand, common law systems, as a general rule, has two distinct stages: pretrial and trial. The main feature of pretrial is the opportunity that parties have to build their cases and the possibility of settling the litigation by conciliation, withdrawal or grant of summary judgment for lack of good cause, i.e., to determine if a cause shows enough evidentiary potential and argumentative support to stand before the trial.

[...]In the United States, as in most common law countries, there is a division of function between pretrial and trial, and formal evidence is introduced in what is usually one concentrated trial.[...] However, there are a number of features of the

3 Also known as Romano-Germanic Legal System, considered the most widespread system of law in the world and widely developed in several continental European countries.

Revista de Direito Brasileira | Florianópolis, SC | v. 27 | n. 10 | p.262-280 | Set./Dez. 2020 
American system of justice that are unique even when compared to other common law systems (CHASE, et al, 2017, p. 43).

Despite the recent reforms that, to a greater or lesser extent, shifted the procedural control of judicial acts (in the pretrial) from parties and lawyers to the courts, the common law standard still grants lawyers a substantial portion of the control of acts in the early stages. The regulations imposed by the reforms in recent decades, however, began to grant more power and conduct to the judge even in the previous stages. ${ }^{4}$

In the daily legal practice of civil litigation in anglo-american Systems, a case will not held in court unless it shows good cause during the pretrial stage. This happens because the pretrial allows the parties to have mutual access to information, data and evidence, under the justification of grounding their factual and legal causes of action.

Pretrial is effective because permits to link the evidence to the facts in the early stages, connecting the introductory acts and the preparatory stage (DONDI; ANSANELLI; COMOGLIO, 2017, p. 142). The pretrial works as a link of interaction and dialogue between the parties and their counselors.

The pretrial stage allows the parties to get the early knowledge of data and evidence that can only occur during a debate, since the main function of the procedural system is to provide a forum for conflict resolution (SWARD, 1989, p. 303). The pretrial stage, in fact, aims to decrease the importance of adjudication and make it useful only for hard and complex cases.

Most of the potential suits presented before anglo-american common law court systems hardly surpass the pretrial stage, i.e., the cases do not even reach the trial stage. In both English and US justice systems, the number of cases that reach the trial stage is very small, and that is exactly why it is so important to understand the functioning of the procedural rules in these countries.

\section{EVOLUTION OF PROCEDURAL RULES IN ENGLAND AND IN THE USA}

In England and in the USA, the set of procedural rules applied to judicial cases is traditionally developed within the court, primarily among judges, because common law has the judge-made law as one of its main characteristics.

In the course of the development of common law, the establishment of procedural rules by the judges generated some inconveniences, since the rules were made to favour their own activity, and eventually the system became curtailed and cumbersome.

The judge-made law system does not make procedural reforms easier, actually it is quite the opposite, since the fellow judges follow rules they have established themselves. In fact, because of the judge-made law, the judges hardly feel encouraged to propose significant changes in procedural rules.

Nonetheless, over time, the reforms introduced in England have created mechanisms that have given greater dynamics to judge-made law, such as the practice directions (PD), which are guidelines issued by the judiciary itself that regulate the application of the law, especially when the Civil Procedure Rules are not sufficiently able to deal with situations (CHASE et al, 2017, p.18).

The reforms carried out by the courts, dating from the late 18th century and early 19th century, sought to eliminate procedural details that seemed to be mere obstacles to the attainment

4 The Woolf Reforms in England, which implemented the new regulatory system based on the Civil Rules of Procedure (CRP), are the best example of shifting control of acts in the pretrial. In the U.S., in turn, recent precedent regarding the pleadings system (Bell Atlantic Corp. v. Twombly -2007 and Ashcroft v. Iqbal -2009) have increased the rigidity of the admissibility criteria and empowered the judge's activity. The paradigm shift in England, however, was much more significant than in the US. 
of substantial law. However, they were not very successful and ended up aggravating the problem they were trying to eliminate, i.e., the excessive formality ${ }^{5}$ (MARCUS, 2008, p. 160).

This unsuccessful experience broke the tradition of procedural reforms handled by the judges themselves, and thus began the first reforms carried out by the English Parliament, substantially modifying procedures without the concern of maintaining privileges and the convenience of judges ${ }^{6}$ (MARCUS, 2008, p. 160).

The typical predominance of conservative rules of the English system, administered in the courts across the country, came to an end in the mid-19th century with the enactment of important legal acts, interrupting and stagnating once and for all the paralysis caused by the excess of rules that were of no practical use and not committed to the efficiency of the procedural system.

In the 19th century, important reforms took place in the justice system through enacted legislative acts, such as the Common Law Procedure Act of 1852, the Trinity Rules of 1853 and the Judicature Acts of 1873-1875.

During the same period, on the other side of the Atlantic, the American system, despite having inherited the English judge-made law, also carried out reforms in its legislation, the most important of them under the format of codes and developed by the Legislative with the main purpose of achieving the simplification of procedures.

The reforming impulse of the North American system, as opposed to what happened in England, took place from the bottom up, i.e., reformist movements emerged from -and were led by - the sectors directly involved with the system (MARCUS, 2008, p. 163).

In the nineteenth century, the U.S. judicial system had already developed its own identity and has moved on from English traditions, establishing as a rule the trial by the jury in civil cases and creating its own model of rule of collection of attorneys' fees. ${ }^{7}$

The New York Field Code of 1848 was an Act that regulated procedures in the civil litigation and established rules that simplified judicial procedures and required fewer formalities, especially in the pretrial stage.

Although it was enacted as a state code, New York Field Code had enormous influence and inspired other states. Over time, twenty-seven U.S. states replicated the contents of the code, becoming the standard model of procedural law in the country (HEPBURN, 1897, p. 88-89 apud SUBRIN, 1998, p. 696).

In the 20th century, the first significant reforming piece of legislation in the US was the Rules Enabling Act of 1934, followed by several others. This sequence of reforms in U.S. procedural law in the mid-twentieth century culminated with the profound transformation caused by the 1938 edition of the Federal Rules of Civil Procedure.

The provisions of the Federal Rules forwarded the simplification of procedures, reducing the excessively technical requirements of pleadings and adopting a revolutionary set of means of elicit evidence, called discovery.

\footnotetext{
5 That was the case with the Rules of Hilary Term, 1834. See Richard L. Marcus, Modes of Procedural Reform, 31 Hastings Int'l \& Comp, p. 160.

6 Having solved the problem of the bias of the reforms that benefited only the judges, another problem arose: the submission of the terms of the reforms to the political pressure of the Parliament, as well as the virtual ignorance of parliamentarians of the routine of the courts. See Richard L. Marcus, Modes of Procedural Reform, p. 160-161.

7 The english system maintained the principle of the loser's succession of fees, while the US created the "american rule", which established that each party was responsible for paying the expenses of its own lawyer. Also, the U.S. consolidated the provision and constitutional guarantee of the jury for civil cases, which had been virtually abandoned in England in the 19th century.
} 


\section{EMERGENCE AND DEVELOPMENT OF DISCOVERY IN ENGLAND}

Discovery is the stage of production and disclosure of evidence in the pretrial, mostly controlled by the parties and their lawyers. Although this method has emerged in English law, it has had highly developed regulation and use in the US state and federal justice systems.

In England, its origin refers to the use in equity courts, when the chancellor was granted the prerogative to determine the production of documents, in a procedure called discovery of documents.

The discovery allows the parties to have access to the documents and information that constitute the case of the adverse party right in the initial stages of the procedure, within the pretrial stage. The adversaries must reciprocally disclose all the information and data about the case.

English discovery, although it has traditionally been applied for centuries by the courts of chancery, was officially made available in all High Court instances only after the edition of the Judicature Acts in 1873-75 (KINDER-GEST, 1997, p. 483).

The developers of the Judicature Acts designed a combination of provisions that had already been used in courts of equity and common law in the past. The discovery in the judicature acts sought to obtain the benefits of the broader principles applied in chancery courts and combine them with the simplicity of common law methods (ROSENBAUM, 1915, p. 58).

Under the Judicature Acts of 1875, the English discovery allowed that, soon after the exchange of pleadings, either party could give the opponent a list of questions, in the form of a document called interrogatory, to be answered under oath and under the risk of application of penalties previously provided for in the legislation (RAGLAND, 1932, p. 18).

More recently, the procedure has undergone a change of nomenclature without, however, losing its main characteristics. With the publication of the Civil Procedure Rules in 1998, the English discovery became known as disclosure, and so it remained as a method by which a party is obliged to disclose to the opposing party, to the court or to third parties, the entire body of evidence that supports its best interests in the claim/defence.

The English disclosure's procedural determines that the party should make available, in advance, a list of the documents it holds in its possession and allows the opposing party to examine, inspect and obtain copies of them. If a party believes that the opposing party is acting in such a way as to omit any of these means of evidence, it must request from the court an order for the opponent to produce these documents (KINDER-GEST, 1997, p. 483).

The parties must disclose not only the evidence supporting their own case but also those information, data and evidence that, eventually, have the potential to harm those who reveal and strengthen the opponent's evidence (SIME, 2002, p. 283). The intrusive nature of this procedure is usually subject of criticism.

The importance of pretrial discovery can be observed more clearly from the perspective of evidence, which plays a central role in any judicial procedure. The control over evidence is crucial for the quality of the judicial system.

The pretrial discovery spotlights the evidence in the very moment the parties are able to resolve the dispute by summary judgment or dismiss. This stage prevents the parties to go before the court to litigate and get into a risky judicial adventure, and also may prevent the establishment of a procedural game often dishonest and uncompromising:

It thus facilitates the 'cards on the table' approach to litigation introduced in the 1990s as well as the achievement of justice on the merits. It also serves to promote equality of arms through providing equal access to evidence. It facilitates settlement by enabling parties to assess the strength of their and their opponent's evidence [...] It also promotes procedural economy by reducing the prospect that parties will be surprised at trial by evidence they have not previously seen, [...] And even where a claim does not settle, where disclosure enables an issue or issue 
to be resolved it narrows the dispute thus enabling the court to deal with the trial more expeditiously (CHASE, 2017, p. 22).

When the pretrial stage closes without settlement between the parties or a withdrawal ${ }^{8}$, the plaintiff may file a motion to the court called summons for directions ${ }^{9}$, and thus the court has the opportunity to make adjustments and requests before the trial, which can take a long time to happen and lengthen the resolution of the case ${ }^{10}$.

The English law has a very peculiar approach in comparison to other common law systems: exclusively the counsel carries out the representation in court and during the trial ${ }^{11}$. He is the one who will effectively represent the plaintiff, articulating the opening allegations before the court and presenting the case to the court.

The counsel's role is to expose the case before the court, proceed with the reading of the pleadings, and summarize the main issues of the dispute by discussing what the witnesses will present later in the course of the trial (KINDER-GEST, 1997, p. 486).

It is important to note that, despite the similarities of the English disclosure with the disclosure under rule 26 of the U.S. Federal Rules of Civil Procedure, there are relevant differences between them. Disclosure in the US composes a broader stage that is the discovery, which has developed many other means of evidence production that go far beyond the mere disclosure of information and documents in the preliminary stages. ${ }^{12}$

\section{THE CURRENT MODEL OF EVIDENCE DISCLOSURE IN THE ENGLISH PROCEDURAL SYSTEM AND THE CHANGING PRECEDENTS}

In the late 1990's the English system went through reforms that established mandatory dialogues between the parties providing opportunity for conciliatory solution and/or the dissemination of alternative dispute resolution (ADR).

These reforms were quite successful and created solutions in the anglo-american system that established instruments that favored the resolution of cases by settlement, withdrawals and summary judgements.

For instance, taking roughly the data of entry and trial in the period before and after the reforms, in 1998, 01 (one) out of 20 (twenty) cases reached the trial stage; in 2004, 01 (one) out of 25 (twenty-five) cases reached this stage (DINGWALL; COATRE, 2006, p. 60).

\footnotetext{
8 Withdrawals and settlements are very common at this stage because, after the disclosure of evidence, the parties are able to foresee the possibilities of a favourable or unfavourable judgment.

9 Upon filing the 'summons for directions', the plaintiff informs the court that the parties are ready for the trial phase, and the court will take the necessary steps for the commencement of the trial, i.e., to determine any action or the inclusion of the trial on the agenda See Non Contentious Probate Rules of 1987, 44 (6), available at http://www.legislation.gov.uk/uksi/1987/2024/body/made. Access on October 20, 2019.

10 Data from the 1990s (more precisely from 1996, the period prior to the Woolf Reforms) reveal that the average time between the initial pleadigs and the trial was 179 weeks (1,253 days), and the average time between the pretrial and trial was 44 weeks (308 days). See Patricia Kinder-Gest, Droit Anglais: Institutions politiques et judiciaires, 1997, p. 483.

11 Counsel is the lawyer responsible for the plaintiff's defense argumentation before the court. On the other hand, the solicitor is the lawyer in charge for the daily follow up of the demand and contact with the parties.

12 American discovery is much more complex than the mere disclosure of documents and information. The discovery rules in the US allows the production of oral evidence (deposition), written evidence (interrogation) and expert evidence (physical and mental examination). See Federal Rules of Civil Procedure, Title V. Disclosures and discovery, Rule 26-37.
} 
This decrease in cases occurred from the period immediately following the Woolf reforms, and the reduction continued in the following years, as can be seen in the official statistical data of the english justice system. ${ }^{13}$

The data shows that in the first quarter of 2018, the county courts -which concentrates the absolute majority of civil cases in England- had 534,400 cases, of which 427,900 dealt with socalled money claims. Of these, 71,800 presented a defense, and only 15,313 reached the trial stage. ${ }^{14}$

There is still a significant percentage of cases that do not reach the trial stage but obtain a decision from the judge (summary judgement). In this same period (first quarter of 2018), 353,500 cases were settled, of which 317,400 (90\%) by default, and 21,947 cases of admission judgments. ${ }^{15}$

The English law provides regulations for disclosure of evidence and other methods that encourage the dialogue between the parties in order to settle the dispute before the case reaches the court stage (presuit or pre-action), such as the 'Pre Action Protocols' ${ }^{16}$. The application of these protocols in the pre-action stage is part of the reforms that assigned to the court more responsibilities in relation to the case management.

The Civil Procedure Rules works as a Procedure Code in England. The general rules of disclosure are set out in this statute in the following terms:

a) the parties have the duty to communicate the existence of a certain document (Part $31.2)$

b) the opposing party has the right to inspect the document presented by the party (Part 31.2);

c) there is no obligation to use the disclosure and may be waived by the court or the parties in a negotiated manner (Part 31.5(1)(b)(c));

d) the parties undertake in writing to tell the truth, and to report on the existence and location of the documents relevant to the case, as well as the costs involved in the disclosure of such documents;

e) no later than 7 days before the first hearing, the parties must, in person or by telephone, discuss the options and reach an agreement on how the disclosure of the documents will develop in order to achieve the best outcome of the proceedings (Part 31.5(5));

f) if the parties reach an agreement and the court agrees to its terms, it may cancel the hearing and determine measures in accordance with what has been established (Part 31.5(6)(a)(b));

$\mathrm{g}$ ) in the event of a hearing, the judge has at his or her disposal a series of measures to achieve the purpose of disclosure, ranging from limiting or waiving the procedure to specific orders for the parties to submit certain documents (Part 31.5(7) and (8));

h) to require which documents will be disclosed, the following factors will be considered: quantity of documents, nature and complexity of the procedure, the level of difficulty in obtaining or recovering the document and the importance of the document (Part 31.7(2));

i) application for disclosure is possible before proceedings have started, i.e. in the presuit stage (Part 31.16);

j) a party may refuse to disclose a document or submit it for inspection on the grounds of damage to the public interest (Part 31.16).19 (1) and (3));

\footnotetext{
${ }^{13}$ Civil Justice Statistics quarterly, England and Wales, january to march 2018, published in June 07- 2018 by the civil justice statistics. Available in https://www.gov.uk/government/statistics/civil-justice-statistics-quarterly-januaryto-march-2018. Acess in july 2019

${ }^{14}$ Civil Justice Statistics Quarterly, England and Wales, January to March 2018 (provisional), p.2

${ }^{15}$ The possibility of pre-action admission is established in PART 14.1.A of the Practice Directions (PD).

16 Pre Action Protocols are a series of preliminary protocols directing the parties in the pre-action stage and encouraging them to communicate and develop dialogue towards the settlement by agreement. The statute that ensures compliance and the legal force of these protocols is the Practice Direction Pre-Action Conduct (PDPAC), in-force in England since 2009, which functions as a general protocol for all civil litigation modalities.
} 
k) if the party fails to display or permit inspection of a document, it may not use it in its favor (31.21);

1) A false disclosure statement from the parties regarding the documents subject to disclosure may be punished by contempt of $\operatorname{court}^{17}$ (Part 31.23).

The use of disclosure in the pre-action stage in English system follow rules that resemble the rules of advanced production of evidence in Brazil ${ }^{18}$. The anticipation of evidence is based on the preservation of evidence, the prevention of the filing of the action or the favouring of selfcomposition.

The disclosure of evidence in the English system, likewise, obeys three main principles: the fair availability of anticipatory procedures; assist the dispute to be resolved without the need for judicial procedure; save costs. ${ }^{19}$

The application of disclosure in the English system was recently changed by two important precedents in two important cases, which are, Fundo Soberano v. dos Santos ${ }^{20}$ and Galagaev v. Ananyev ${ }^{21}$. In the mentioned cases the court decided that disclosure is mandatory for the parties and lawyers, regardless of notification.

Failure to disclose, even without the motion of the opposing party, is liable to punishment. In the precedent case Fundo Soberano v. dos Santos, when one of the parties failed to disclose important information, it suffered the freezing of a fund in the amount of 3 billion dollars. This decision established a precedent regarding the duty to disclose evidence in the pretrial called $d u t y$ of full and frank disclosure.

At the time of the trial of this case, Judge Popplewell, of the Commercial Court (High Court's), argued in order to reinforce the duties of the parties and lawyers before the parties in the application of the disclosure:

the duty is not confined to the applicant's legal advisers but is a duty which rests upon the applicant itself. It is the duty of the legal team to ensure that the lay client is aware of the duty of full and frank disclosure and what it means in practice for the purposes of the application in question; and to exercise a degree of supervision in ensuring that the duty is discharged ( [2018] EWHC 2199 (Comm), p. 21)

That said, it is fair to say that the most recent precedents of the English courts confirms the duty to disclose evidence under the control of the parties ${ }^{22}$, which may be required immediately and independently of a request or court order.

\section{DISCOVERY IN THE UNITED STATES}

The US legal system has developed a more advanced procedural instruments in the pretrial stage than England's, in particular the advanced tools and mechanisms of discovery ${ }^{23}$. The U.S. system build a more liberal procedure, by developing tools which allowed the control of procedural

17 The contempt of court might be understood as the equivalent of the "ato atentatório à dignidade da justiça" from the Brazilian system.

18 Advance Production of Evidence. Brazilian Civil Procedure Code, Art. 381.

19 Civil Procedure Rules Part 31.16(3)(d).

20 Fundo Soberano de Angola \& Ors v. José Filomeno Dos Santos \& Ors [2018] Ewhe 2199 (Comm). Case No: Cl2018-000269.

21 Galagaev \& Ors v. Ananyev \& Ors (2018) Qbd (Comm).

22 Control of the parties means the evidence which the parties have under their physical possession or within the scope of their influence.

23 The possibility of depositions, interrogatories, physical examination, etc.

Revista de Direito Brasileira | Florianópolis, SC | v. 27 | n. 10 | p.262-280 | Set./Dez. 2020 
acts and production of evidence between the parties without participation and direct interference of the court.

The methods and mechanisms of the common law were not immediately adopted by the colonies in the United States. However, over time common law gained ground and, in the first half of the 19th century, U.S. courts followed, with minor differences, the general patterns of discovery developed in English courts. The procedure, however, was cumbersome, expensive, and problematic (TEPLY; WHITTEN, 2000, p. 738).

More recently, at the beginning of the 20th century, US federal procedural system has been reformed and established mechanisms that implemented their liberal view of the production of evidence and the scope of the adversarial system.

The development of the new system in the US borrowed the characteristics of discovery instruments developed in the states ${ }^{24}$ and in foreign law. Sunderland ${ }^{25}$ managed to develop a wellstructured system that was immediately received by the federal courts (MARCUS, 2008, p. 165166).

Sunderland, who was a practical man, was very critical of systems that allowed inconsistent, fraudulent and fictitious claims and defences to thrive in courts, causing difficult situations to circumvent and confusion in the trial (SUBRIN, 1998, p. 691).

It is probable that no procedural process offers greater opportunities for increasing efficiency of the administration of justice than that of Discovery before Trial [...] Much of the delay in the preparation of a case, most of the lost effort in the course of the trial, and a large part of the uncertainty in the outcome, result from the want of information on the part of litigants and their counsel as to the real nature of the respective claims and the facts upon which they rest (RAGLAND, 1932, Sunderland preamble).

Sunderland understood that a justice system that allows parties and lawyers to hide evidence from their opponents and from the court becomes responsible for the lack of understanding of these same litigants and lawyers regarding the case.

In 1935, when Sunderland began to draft the rules of discovery ${ }^{26}$, the use of discovery in federal courts in both equity and law cases was absolutely reduced (SUBRIN, 1998, p. 698).

The Federal Rules of Civil Procedure of 1938 changed discovery considerably by including the possibility of oral depositions without the presence of a court official (SUBRIN, 1998, p. 703). The rules have provided that there was no obligation for the presence of an authority (clerk) to establish objection criteria and constrain the issues.

This liberal status allowed the lawyers to control the acts in accordance with the direction they intended to take in the case ${ }^{27}$. The prerogative of absence of a court official established by the federal rules was to be applied to cases at the federal level, while states were not required to follow this guideline $\mathrm{e}^{28}$.

24 Because of their legislative autonomy, the states already implemented more advanced rules in relation to the instruments of the pretrial. Some of them were eventually adopted by federal legislation. The federal rules, in turn, also influenced the legislation of the states that had not yet adopted the rules.

25 Edson Sunderland (from University of Michigan) and Charles Clark (Yale) were appointed by the Supreme Court to organize the reforms that began with the Rules Enabling Act of 1934 and culminated in the 1938 edition of the Federal Rules of Civil Procedure.

26 These drafts would become rules 26 to 37 of the Federal Rules of Civil Procedure, which are still applicable.

27 In England, with the edition of the Civil Procedure Rules in 1998, case management has become responsibility of the court.

28 During this period, in the states of New Hampshire and Missouri, depositions were held before an officer with powers to limit questions and to grant objections. In Indiana, Kentucky, and Texas, if any objection could not be settled between the parties' attorneys, the act would be postponed until the court established a rule to pacify the matter. See

Revista de Direito Brasileira | Florianópolis, SC | v. 27 | n. 10 | p.262-280 | Set./Dez. 2020 
Since there was no obligation to apply the federal rules in the states, it was necessary to uniform the practice of discovery instruments among all of them; thus, many states adopted the Uniform Interstate Depositions and Discovery Act (UIDDA) ${ }^{29}$.

The Federal Rules also changed the rules for oral depositions, which initially covered only the hearing of the parties, allowing the hearing of witnesses, also without the need for the presence of a court official.

The new rule also allowed the parties to inspect each other's property and make copies or inspections of documents found in the possession of the other party. ${ }^{30}$

Some scholars claimed that the excess of possibilities would cause some problems in the use of discovery, such as the resistance of the lawyers to reveal documents and other evidence in the possession of their clients to avoid weakening the case. They also alleged that discovery would cause the fade of merit judgement, waste of time with rules and motions and finally that the wide use of discovery would reduce the frequency and importance of trials (SUBRIN, 1998, p. 706707).

Indeed, the reduction in the importance of adjudication is a fact in the anglo-american system.Most states in the US show a very small number of cases that reach trial. This is because most cases are settled via conciliation or granted summary judgment.

In a comparative and quantitative analysis between U.S. and Brazilian case data, it is important to note that even the introduction of the new code of procedural law in 2015 was not sufficient to reduce the number of cases efficiently.

It was expected that with the enactment of a new procedure code, the conciliation rates would increase expressively, which did not occur. The number of new cases continues to grow, with the demand for the justice system registering an accumulated growth of $18.3 \%$ in the eightyear period, considering the entire historical series since 2009, since the report discloses data from the previous year, $2017^{31}$

The report reviewed cases in progress in all levels of courts and jurisdictions of brazilian justice. The distribution is highly concentrated in the state jurisdiction. In fact, brazilian state courts concentrates $79.4 \%$ of the pending cases, the federal courts 13.8 of the cases, the labor courts 5.9 and the other segments together add up to $0.9 \%$ of the pending cases. (CNJ, 2020, p. 94 and CNJ, 2018, p. 72)

Comparatively, in the U.S., the indices of the historical series took the opposite path. The number of cases that have entered the justice system of the states - which holds approximately $95 \%$ of the total number of cases - fell by $19 \%$, from 103.7 million in 2007 to 84.2 million in $2016 .{ }^{32}$

\footnotetext{
Stephen N. Subrin, Fishing expedition allowed: the historical background of the 1938 federal discovery rules, 1998, p. 703.

29 The standardizing legislation is important because in situations where the procedural acts exceed the territorial limits of the states, it is necessary to apply rules that can harmonize the application of interstate procedural rules, a situation that was not the object of the Federal Rules.

30 The previous rule, so-called 'limited discovery', required the parties to submit an application for inspection upon justification (showing good cause) and there was limitation to inspect and copy only documents and materials related to the cause. The current rule (rule 26(c)) has an inverse conception: the party may request the court not to disclose documents and evidentiary elements through a "showing good cause". See Federal Rules of Civil Procedure 26(c).

${ }^{31}$ The 2018 CNJ report showed that in 2017 more than 20 million new cases (more precisely 20,207,585) entered the state courts alone. Available at http://www.cnj.jus.br/files/conteudo/arquivo/2018/08/44b7368ec6f888b383f6c3de40c32167.pdf

${ }^{32}$ Curiously, civil cases are not among the most expressive numbers in the US state system. Traffic violations lead the way $(53.3 \%)$, followed by criminal $(21.2 \%)$, civil $(18.1 \%)$, domestic relations $(5.9 \%)$ and infractions committed by minors (1.5\%). Available at http://www.courtstatistics.org/NCSC-Analysis/National-Overview.aspx.. Acess may 202019.
} 
As a comparative quantitative analysis, the state courts in the U.S. had approximately 84 million cases in the district courts, and 257,000 cases in state courts of appeal. It is worth remembering that approximately $95 \%$ of the lawsuits in the U.S. are processed in state courts. ${ }^{33}$

The data above reveals that proportionally the number of cases being processed in the USA and England is much lower than in Brazil, and the trend of reduction of cases in common law systems started longer ago and tends to continue

Besides that, the recent precedents about the pleadings increased the demand for description as well as the rigidity for admission of cases affects the use of discovery as a possible safeguard for those who are unable to demonstrate the force of their case in the initial application.

According to Hubbard (2013, p.1), it is well known that Twombly and Iqbal ${ }^{34}$ have introduced a regime of "plausibility" pleading to replace the prior "notice" pleading. As a result, a much larger share of motions to dismiss were granted, and fewer lawsuits have been filed.

\section{THE COSTS OF PRETRIAL DISCOVERY}

The two precedents above mentioned have changed the pleading standards, consequently the plaintiffs were impacted with larger costs, because the plausibility pleading standard ${ }^{35}$ requires a better prior search for evidence to support the suitcase.

Expenses and economic factors in general should be largely considered when one suggests to introduce disclosure of evidence in a civil law system. The increase of costs generated by discovery is the major criticism of its users and one of the reasons why is hardly used in some states.

Dodson (2010, p. 73), for example, defends the restricted use of discovery, not because it's liberal features or excessive flexibility, but because implies an excessive increase in costs. The excessive costs harms both the plaintiff who has a solid complaint and the defendant with enough ground to grant a motion for dismiss.

On the other hand, contrary to this argument, there is the idea that discovery can prevent complaints that are unable to show good cause at the pretrial stage:

frivolous suits all settle early, producing little in the way of wasted litigation costs, and settlements are likely to be quite small unless, for some reason, the stakes are unusually high. Moreover, defendants in some (perhaps many) cases should be able to deter frivolous suits on their own by using a fighting strategy (BONE, 1997, p. 541).

In this sense, the more affordable a lawsuit is, the more the system encourages frivolous and meritless claims. On the other hand, the defendants would rather to be submitted to intrusive discovery rather than having to bear the costs of a judicial proceeding, even if it is inadmissible (DODSON, 2010, p. 73).

If the defendant (or a hostile third party) actually knows whether the case has or lacks merit, then forcing him to show his cards in a limited and targeted way is better for the court, the justice system, and all parties (HOFFMAN, 2008, p. 35, apud DODSON, 2010, p. 74).

In any case, the expenses with discovery in the pretrial should be considered sparingly. However, the absence of the discovery tools would transfer the lawsuit expenses to the next stage anyway, whether it was controlled by the parties themselves or by the court.

\footnotetext{
${ }^{33}$ The federal courts, in turn, have their cases distributed in 3 courts, namely the district courts (368 thousand cases), bankruptcy courts (795 thousand cases) and appellate courts (60 thousand cases). Available at http://www.courtstatistics.org/ e http://www.courtstatistics.org/NCSC-Analysis/National-Overview.aspx. Acess may 20-2019.

34550 U.S. 544 (2007) and 556 U.S. 662 (2009).

35 Requiring a more complete description of the facts.
}

Revista de Direito Brasileira | Florianópolis, SC | v. 27 | n. 10 | p.262-280 | Set./Dez. 2020 


\section{VIRTUAL APPLICATION OF PRETRIAL REGULATION AND INSTRUMENTS IN THE BRAZILIAN PROCEDURAL SYSTEM}

The pretrial instruments were designed to reach practical results in the anglo-american system, giving priority to the wide, unrestricted and reciprocal disclosure of evidence in the early stages of the procedure.

Common law tradition has allowed the development of procedural tools that enable the parties to have wide access to the opposing party's information and evidence in the pretrial, i.e., before the court itself acknowledge the full facts. As a result, the adjudication will take place only when the adversarial system is not sufficient to settle the dispute.

A judge or a lawyer functioning in a civil law system will find quite impressive the amount of cases that settled and withdrawn in the anglo-american pretrial stage, as well as the positive impacts on the numbers of the justice system and on user satisfaction rates.

However, at first, it is unlikely to imagine that the discovery tools or methods can be implemented in the Brazilian system without great obstacles and challenges. This is because the anglo-american system spent many decades developing a liberal tradition that can't be easily assimilated by a system deriving from civil law.

Civil litigation in the Anglo-American system operates into two clearly specific stages, pretrial and trial. brazilian procedural system, in turn, following the continental tradition of the European law, keeps the procedure in a continuum jurisdictional phase, in four steps fully and directly controlled by the judge, which are, pleadings (plaintiff's and defendant's), mediation/conciliation hearing, production of evidence, adjudication.

In the adversarial system, the parties can produce and have full access of evidence in the pretrial discovery, which imposes on the parties stricter rules to face each other in the field of argumentation, stimulated by the disclosure of data and information about the complaint.

While the anglo-american model developed specific and elaborate regulation for the parties and lawyers in order to control the production and disclosure of evidence, the opposite occurred in civil law, where the judge is widely responsible for the collection and production of evidence, with an active role controlling procedural acts related to the evidential activity.

In fact, the different conceptions of the production of evidence in civil law and common law traditions are largely attributed to the model of performance of judges and lawyers in the case management. In the adversarial system developed from the Anglo-Saxon law, the sovereign and ineligible role of the jury as the "judge of facts" removed the interference of the judge from the pretrial stage $^{36}$ (BARBOSA MOREIRA, 2003, p. 57-58).

Despite the virtual disappearance of the jury for civil cases in England and the low number of trial by the jury in civil cases in the USA, this was once a remarkable feature of the system:

even where the reasons for the phenomenon had ceased, its consequences would continue to be felt - not only, in fact, the predominance of the parties over the judge in the investigative activity, but also the concentration of the latter in the trial session and the preference, now partially attenuated, for oral evidence (BARBOSA MOREIRA, 2003, p. 58).

36 The use of the jury in civil cases in England has not been formally abolished, however, it has long since gone into decline, the adjudication is a responsibility of the judge in virtually all jurisdictions. In the United States, by contrast, although jury-trial of civil cases is not the most common form, legal provision prevails because it is a constitutional principle, and many states apply this prerogative to resolve civil cases. About the institute of the jury in US civil cases, see US Constitution, Amendment VII. For comments on the Seventh Amendment to the U.S. Constitution, see also https://constitution.findlaw.com/amendment7/annotation01.html\#1. Access on October 21, 2019. 
In the evidentiary field, the adversarial system determines that the obtaining/production of evidence for the trial is a prerogative of the parties. In civil law systems, on the other hand, following the paradigm established by the inquisitorial principle, this is a role of the judge. In common law it is frowned upon the idea of a judge that investigates the witnesses and parties, or take any evidentiary initiative, under penalty of violating the principle of fair trial ${ }^{37}$ (BARBOSA MOREIRA, 2003, p. 59).

More recently, the English system, especially after the Woolf Reforms in the 1990's, has been restricting the control of lawyers and parties on the case management. After having encountered situations of collapse arising from excessive rules, unreasonable complexity and poor execution of lawyers, the reforms are gradually giving the court greater control of case management.

This detachment didn't repeated with the same emphasis in the US system, where the liberal development of the pretrial, especially the discovery instruments ${ }^{38}$, kept the production of evidence under the control of lawyers, and the trial under the judge's/jury responsibility.

Despite the establishment of important precedents in the 2010s, which simply reconfigured the use of discovery ${ }^{39}$, the evidence production in the US procedural system remained in the control of lawyers and parties.

There is much discussion about the extent to which the judge should control procedural acts. Thus, some legal systems emerged from civil law tradition have promoted reforms aimed at increasing or decreasing the judge's powers in the case management.

The German legal system, for instance, introduced reforms in 2001 that changed its procedural system in order to increase the judge's investigative powers. It allowed the presentation of evidence not only to the claimant but also in relation to the documents referred to by the opposing party or third parties ${ }^{40}$ (BARBOSA MOREIRA, 2003, p. 62).

This reform of the German system appears to have conceptual identification with the format developed by discovery in the USA, where the disclosure of documents is mandatory for both plaintiff and the defendant. However, the control of the evidentiary acts remains with the judge.

Spain and Italy, in their turn, do not show the same inclination for reforms in that direction. In these countries, lawyers and parties do not have the same obligations during the evidencegathering stage, nor have more liberal measures been implemented in relation to the disclosure of evidence.

The Spanish legislation is similar to the Brazilian legislation in terms of control of evidence, establishing the need to request the presentation of evidence as a general rule, and providing, in article 282 of the Ley de Enjuiciamiento Civil of 2000, that the court may determine the production of evidence when the law provides so.

In Italy, both criminal and civil procedural legislation clearly reject a publicist view of the litigation, with a tendency to contradict measures that would allow the expansion of participation of the court in the collection of evidence (BARBOSA MOREIRA, 2003, p. 63).

The procedural regulation of most South American countries, until the end of the nineteenth century, was a mere derivation of Spanish legal culture. However, some countries began

37 The fact that the majority of US judges is chosen by election means that there is a concern among the judges about the image they convey to lawyers. See José Carlos Barbosa Moreira, op.cit, 2003, p. 59 . In England, something similar occurs, since most judges are chosen from among the counsels acting in the courts.

38 Federal Rules of Civil Procedure, Rule 26-37.

39 Already mentioned Twombly and Iqbal. See note 31.

40 Zivilprozessordnung, §142 Anordnung der Urkundenvorlegung (1): The court may order a party or a third party to produce the documents and other documents in its possession to which one of the parties has referred. ("Das Gericht kann anordnen, dass eine Partei oder ein Dritter die in ihrem oder seinem Besitz befindlichen Urkunden und sonstigen Unterlagen, auf die sich eine Partei bezogen hat, vorlegt)"(author's translation). 
to manifest peculiarities and developed autonomy thereafter (DONDI, ANSANELLI; COMOGLIO, 2017, p. 144).

In turn, the Brazilian legislation, which largely reflects the Romano-Germanic law developed in the continental Europe countries, continues regulating the conduction of judicial acts by the judge in all stages of proceedings.

The development of the Brazilian procedural system has not been separated from all common law influences. On the contrary, many legal-procedural institutes developed by the angloamerican systems have been used by the Brazilian legal culture (BARBOSA MOREIRA, 2001, p. $13)$.

In Brazil, the 1939 Civil Procedure Code reflected the ideas that had great relevance in European countries in the first decades of the twentieth century, especially the reformist ideals and the Italian doctrinal movements that, in turn, would never succeed there (BARBOSA MOREIRA, 2001, p. 12-13).

The Civil Procedure Code of 1973, more eclectic, was inspired by the Italian, Portuguese and even German civil litigation rules. Barbosa Moreira (2001, p. 13) draws attention to a regulation act that would also have influenced the 1973 CPC and of which there is little reference, the 1946 Codice di procedura civile dello Stato della Città de Vaticano, strongly influenced by Francesco Carnelutti.

The current regulation (Civil Procedure Code of 2015) didn't bring many changes in relation to the case management control on evidence, maintaining the prerogative of the judge in this role, producing evidence ex officio or at the request of the parties.

There are a few steps that must be observed by the judge before determining the production of ex officio evidence, mainly when there's no requirements by the parties. In other words, article 370 of the CPC/2015 requires great sense of responsibility from the judges in order to avoid the erroneous application of the burden of proof as a rule of judgment (CAMBI; DOTTI; PINHEIRO; MARTINS; KOZIKOSKI, 2019, p. 683).

In the Brazilian procedural system, the judge takes control over the evidence production and determines which types of evidence the parties will produce. It also grants them the opportunity to make requests in this regard, regardless requests from the parties.

\section{THE BRAZILIAN SYSTEM AND THE ADJUSTMENT OF THE DISCOVERY RULES}

As demonstrated, pretrial disclosure and discovery are methods of sharing evidence between the parties. The proper way of adjust some of the disclosure methods and discovery tools in the Brazilian, rather than create a whole new regulation, system would be to build upon the existing structure of the procedural rules (Código de Processo Civil) and expand its regulation.

The production of evidence in the presuit stage is regulated by the Brazilian civil procedural system by article $381 \mathrm{CPC} / 2015$ and provides for three possibilities of obtaining evidence in the presuit, as follows: I - when it is or will become impossible or very difficult to collect data and evidence during the future lawsuit ${ }^{41}$; II - when the evidence produced is able to favour settlements between the parties ${ }^{42}$; III - when the production of evidence is capable of avoiding the filing of a lawsuit ${ }^{43}$.

The final version of the Brazilian Civil Procedure Code (CPC/2015) allowed something that was already advocated by legal experts when its original bill was still in progress, which is the possibility of granting the motion even when absent the requirement of urgency.

41 CPC/2015 art. 381, inciso I ("haja fundado receio de que venha a tornar-se impossível ou muito difícil a verificação de certos fatos na pendência da ação").

42 CPC/2015 art. 381, inciso II ("a prova a ser produzida seja suscetível de viabilizar a autocomposição ou outro meio adequado de solução de conflito").

43 CPC/2015 art. 381, inciso III ("o prévio conhecimento dos fatos possa justificar ou evitar o ajuizamento de ação").

Revista de Direito Brasileira | Florianópolis, SC | v. 27 | n. 10 | p.262-280 | Set./Dez. 2020 
The change caused by the new proceedings represented the rupture of a legislative paradigm that had long been questioned by lawyers and academics. This procedural technique established the existence of an autonomous right to evidence (CAMBI; DOTTI; PINHEIRO; MARTINS; KOZIKOSKI, 2019, p. 737), not only for use in the judicial formal procedure, but also as an individual right for the parties.

The Civil Procedure Code $(\mathrm{CPC} / 2015)$ has introduced a new perspective to the evidence presentation, increased the list of evidence that could be produced in the presuit stage, even outside the scope of a lawsuit.

Before the enactment of CPC/2015, professor Flávio Luis Yarshell had already wrote about the expansion of the presuit discovery limits ${ }^{44}$. Fredie Didier Jr. (et al, 2014, p.248), similarly, advocated the protection of evidence as a personal right of the parties, i.e., the autonomous right of constituting evidence in court. In the same way Daniel Assumpção Neves (2008, intro) pointed out the need to adopt a "generic and autonomous production of evidence" ${ }^{45}$ and autonomous actions that had as main intent the production of evidence.

According to Talamini (2016, p. 66), after all, there are some situations in which the evidence becomes the very purpose of the lawsuit. The dispute's establishment and resolution, in this case, can only happen around the evidence itself, i.e., once the evidence is presented, the dispute is over.

In fact, the urgent nature of the presuit discovery of evidence was already widely discussed in the CPC/1973. Although some scholars, such as (Supreme Court Justice) Luiz Fux and Nelson Nery $\mathrm{Jr}^{46}$, until recently defended the maintenance of the urgent nature of the presuit discovery, most experts understand that the urgency factor is not essential for granting the motion.

Unlike the presuit and pretrial in the anglo-american law, the Brazilian procedural regulation establishes that in order to granting presuit evidentiary motions there has to be present the "periculum in mora" factor, which means, the motion will be granted only if the urgency criteria is verified.

Periculum in mora refers to a situation where the motion should be granted due to safeguarding the useful outcome of the lawsuit considering the time lapse, while motions related to evidence should be granted by the mere demonstration of the impossibility of producing evidence in the future (NEVES, 2008, p. 495).

The discovery of evidence in the presuit is directly related to the autonomous right to evidence, therefore, the collection of evidence is not directly related to the litigation in court, that is to say, it does not depend on the contrary party's consent or dissent (DIDIER JR.; BRAGA, 2013, p. 7-8).

Lately, with the recent regulation $(\mathrm{CPC} / 2015)$ and the wider possibilities of use of discovery of evidence in the presuit, this method has grown and it is no longer an accessory character of potential use, but instead might gain in the future, autonomy as the main instrument of production of evidence.

It is impossible to compare the regulation of discovery of evidence in Brazil to the liberal approach of presuit and pretrial discovery in the common law tradition ${ }^{47}$. In fact, the recent

\footnotetext{
44 See Antecipação da Prova sem o requisito da Urgência e direito autônomo à prova. São Paulo: Malheiros, 2009. 45 Generic autonomous probationary caution.

46 Luiz Fux and Nelson Nery Jr. were in favor of the more conservative position of the institute, following the jurisprudential trend that pointed in the same direction. See Curso de Direito Processual Civil. 3.ed. Rio de Janeiro: Forense, 2005, p. 1633-1634; e Código de Processo Civil Comentado. 3.ed. São Paulo: RT, 2006, p. 960. Other authos such as Luiz Guilherme Marinoni and Sérgio Arenhardt shared this opinion. They believed that the granting of the presuit motions should deal exclusively with procedural issues which, in turn, would safeguard the material law discussed in the lawsuit. See Processo Cautelar. São Paulo: RT, 2008. p. 258-259.

47 By liberal approach we can understand that in common law justice systems these instruments are much more empowered, independent and self governed that in the civil law systems.
} 
regulation put the Brazilian procedural framework in line with what was adopted by other countries, such as Germany and France (YARSHELL, 2016, p. 117).

To accommodate the American version of presuit discovery (as it is) in the Brazilian system, small changes are required in the Brazilian presuit discovery ${ }^{48}$ regulation in order to allow the application to a greater diversity of cases.

The adaptation mentioned above would require the obligation for the parties to disclose all information and documents regarding the potential claim in a drafted request similar to the anglo-american disclosure.

It might be necessary to split the procedure in 2 stages, as occurs in the anglo-american system, but this is a dramatic change that would require many legislative changes and reforms in order to expand the possibilities of presuit discovery mechanisms, based on the principle that evidence as an autonomous right of the parties.

The most radical legislative change would establish a provision of mandatory disclosure of documents and data/information regarding the location and access to all evidence under the control of the parties, which is very similar to what occurs in the disclosure of the Anglo-American system.

Alternatively, in order to avoid the negative impacts of the introduction of such a liberal instrument in the brazilian procedural system, the regulation could provide that the parties, before filing a lawsuit, could choose to use the presuit discovery in order to obtain evidence in the domain of the opposing party or third parties, regardless of the current requirements of Article 381 and its items and subitems.

In this proposal of the mandatory presuit disclosure, the party that hinders or refuses to present the evidence and information under its control would be subject to sanctions, in particular to bear the expenses of the production of evidence during the actual lawsuit.

In short, this article proposes the regulation of a pre-suit stage in the Brazilian procedural system that allows the parties to exchange pre-existing evidence and information on the possible litigation without the need to make motions or even initiate a lawsuit.

It is important to state that the current procedural regulation in Brazil (CPC/2015) allows this reform, since the expansion of possibilities provided demonstrates that evidence can and should be seen as an instrument of dispute resolution, and not an exclusively procedural use addressed to the court and intended to confirm the claims of the parties.

\section{CONCLUSION}

The English and US justice systems are known for the low number of cases pending trial; that is, only a small percentage of disputes are resolved via adjudication. In general, few lawsuits actually reach the trial stage, and most of them are dismissed by settlement or by withdrawal at the pretrial stage.

The impressive outcomes above mentioned are only possible due to the procedural model of anglo-american civil litigation, derived from English common law, which has implemented both in England and the United States highly efficient dispute resolution mechanisms and which are responsible for closing a large number of cases before a court decision.

Among these mechanisms responsible for the high number of early terminations, the most efficient are those that promote the disclosure of information reciprocally between the parties and encourage dialogue aimed at closing the dispute between them.

This article presents anglo-american disclosure/discovery as an important solution that can be adjusted to the Brazilian justice system. The article also highlighted the precedents of 
English case law responsible for ensuring maximum clarity on the daily use of disclosure, which became known as duty of full and frank disclosure.

The reaffirmation of this method means that the parties must not only disclose all the information about the case, but also expressly point out where they are located, thus preventing them from passing unnoticed and getting lost in the disclosure stage.

Another possible solution from the anglo-american system is the homonym of the English disclosure, also named disclosure in the American system, which has a similar function, but is part of the discovery stage.

Based on foreign procedural solutions, the article defends the adaptation of the disclosure/discovery to Brazilian system, always considering the necessary precaution for the adjustment of methods developed in foreign systems with very peculiar origins and characteristics.

Hence, it is appropriate to propose small changes to the procedure system in order to expand the use of presuit discovery, especially in relation to the regulation of preliminary production of evidence in order to avoid judicial litigation or to facilitate the conciliation on the same.

Such improvement of the institute for the preliminary production of evidence of CPC/2015

${ }^{49}$ may expand the possibilities of disclosure of evidence and impose on the parties the duty to reciprocally present data, information and evidence that may contribute to the immediate resolution of the dispute, favouring self-composition, avoiding the filing of groundless lawsuits and the excessive number of lawsuits in Brazilian courts.

\section{REFERENCES}

BARBOSA MOREIRA, José Carlos. O processo Civil Brasileiro entre dois mundos, 2001, Revista da EMERJ, v. 4, n. 16, 2001.

. O Processo Civil Contemporâneo: um enfoque comparativo, Revista da EMERJ, v. 6, n. 24, 2003.

BRASIL. Conselho Nacional de Justiça. Justiça em Números 2018: ano-base 2017/Conselho Nacional de Justiça - Brasília: CNJ, 2018. Disponível em: http://www.cnj.jus.br/pesquisasjudiciarias/justicaemnumeros/2016-10-21-13-13-04/pj-justica-em-numeros

CAMBI, Eduardo; DOTTI, Rogéria; PINHEIRO, Paulo Eduardo d'Arce; MARTINS, Sandro Gilbert; KOZIKOSKI, Sandro Marcelo. Curso de Processo Civil completo. $2^{\mathrm{a}}$ ed. São Paulo: RT, 2019.

CHASE, Oscar G.; HERSHKOFF, Helen; SILBERMAN, Linda; SORABJI, John; STÜRNER, Rolf; TANIGUCHI, Yasahei; VARANO, Vicenzo. Civil litigation in comparative context. ed. Oscar G. Chase and Helen Hershkoff, West Academic, 2017.

DAMASKA, Mirjan. The uncertain fate of evidentiary transplants: Anglo-American and Continental Experiments, American Journal of Comparative Law, vol. 45, 1997. 
DINGWALL, Robert; CLOATRE, Emilie. Vanishing Trials: An English Perspective, v.1-2006 Journal of Dispute Resolution 51-70, 2006.

DIDIER JUNIOR, Fredie; BRAGA, Paula Sarno. Ações probatórias autônomas: produção antecipada de prova e justificação. Revista de Processo, v. 38, n. 218, p. 13-45, abr. 2013.

DIDIER JUNIOR, Fredie; CUNHA, Leonardo Jose Carneiro da; BRAGA, Paula Sarno; OLIVEIRA, Rafael Alexandria de. Curso de Direito Processual Civil. Vol.2. $9^{\mathrm{a}}$ ed. Salvador: Juspodivm, 2014.

DODSON, Scott. New Pleading, New discovery, Issue I, Michigan Law, vol. 109, Review. 53, 2010.

DONDI, Ângelo; ANSANELLI, Vincenzo; COMOGLIO, Paolo. Procesos civiles em evolución: uma perspectiva comparada. Tradução de Jose María Salgado. Madrid: Marcial Pons, 2017.

HUBBARD, William H.J., Two Models of Pleadings, (unpublished working paper) 2013.

KINDER-GEST, Patricia. Droit Anglais: institutions politiques et judiciaires. $3^{\circ}$ ed. Paris: Librairie Générale de Droit et de Jurisprudence (LGDJ), 1997.

MARCUS, Richard L., Modes of Procedural Reform, 31 Hastings Int'l \& Comp. l. Rev. 157, 2008.

NEVES, Daniel Amorim Assumpção. Ações Probatórias Autônomas. São Paulo: Saraiva, 2008.

RAGLAND, George, Jr. Discovery before trial. Chicago: Callaghan and Company, 1932.

ROSENBAUM, Samuel. Studies in English Civil Procedure. II. The Rule-Making Authority, University of Pennsylvania Law Review and American Law Register, Vol. 63, No. 3 (Jan., 1915).

SIME, Stuart. A practical approach to civil procedure. $5^{\mathrm{a}}$ ed. Oxford: Oxford Univ. Press, 2002.

SUBRIN, Stephen N. Fishing expedition allowed: the historical background of the 1938 federal discovery rules, Boston College Law Review, v.39:69, 1998.

SWARD, Ellen E. Values, Ideology, and the Evolution of the Adversary System, Indiana Law Journal: Vol. 64 : Iss. 2 , Article 4, 1989.

TALAMINI, Eduardo, Produção antecipada de prova no Código de Processo Civil de 2015 Revista de Processo, vol. 260, p. 75 - 101, Out / 2016.

TEPLY, Larry L.; WHITTEN, Ralph U.. Civil Procedure. New York: Foundation Press, 2000.

YARSHELL, Flávio Luiz. Antecipação da Prova sem o requisito da urgência e direito autônomo à prova. São Paulo: Malheiros, 2009. 